\title{
Complement Activation in Cystic Fibrosis Respiratory Fluids: in Vivo and in Vitro Generation of C5a and Chemotactic Activity
}

\author{
ROBERT B. FICK, JR., RICHARD A. ROBBINS, SUSAN U. SQUIER, WILLIAM E. SCHODERBEK, \\ AND WESLEY D. RUSS \\ Pulmonary Disease Division, Department of Internal Medicine, University of Iowa College of Medicine, \\ Iowa City. Iowa 52242; and the Pulmonary Section, Department of Medicine, University of Nebraska and VA \\ Medical Center, Omaha, Nebraska 68105
}

\begin{abstract}
Experiments performed in vitro have demonstrated that leukocyte neutral proteases produce an important mediator of inflammation, $\mathrm{C5a}$, by proteolysis of the $\mathbf{C} 5$ component of the complement system. Cystic fibrosis (CF) lung fluids were characterized by high levels of neutrophils (39\% of total cells versus $2 \%$ in normals) and contained significantly elevated amounts of elastolytic activity (mean $17.7 \mathrm{ng} / \mu \mathrm{g}$ total protein) compared to the lung fluids obtained from normal volunteers $(0.2 \mathrm{ng}$ elastolytic activity $/ \mu \mathrm{g}$ protein, $p=0.001$ ). The objective of these studies was to determine if complement activation and complement-derived chemotactic activity are present in CF lung fluids. $\mathrm{C} 3 \mathrm{c}$ peptide representing activation of $\mathrm{C} 3$ could not be identified in the bronchial-alveolar lung lavage fluids of normal subjects but was readily identified by means of crossed immunoelectrophoresis in CF lung fluids $(n=9$, mean $49 \%$ of $C 3$ ); the mean level of $\mathrm{C} 3$ was decreased in CF lung specimens. Chemotactic activity was significantly elevated in lung fluids of the CF patients when compared to normal lung fluids. Using gel-filtration chromatography and a sensitive radioimmunoassay the chemotaxin present in $\mathrm{CF}$ specimens was identified as the anaphylatoxin C5a. C5a levels in the bronchial-alveolar lavage fluids of CF patients was inversely related to volume in liters expired in $1 \mathrm{~s}$ of a forced expiratory maneuver expressed as a percent of vital capacity determined from a forced expiratory maneuver $(r=-0.72)$. Because there was a direct relationship between the total elastolytic activity present in CF airways and the concentration of C5a ( $r=0.97, p=$ 0.03 ), it was postulated that airway proteases with elastolytic activity also cleave $\mathrm{C}$, nonimmunologically producing C5a. Detailed inhibition assays revealed that much of the total elastolytic activity had the inhibition profile of a serine proteinase. The levels of the serine proteinases were closely correlated with the numbers of neutrophilic leukocytes present per $\mathrm{ml}$ of lavage fluid $(r=0.7, p=0.05$ ). However, inhibitors of leukocyte serine proteases did not prevent the generation of additional chemotactic activity
\end{abstract}

Received January 30, 1986; accepted July 22, 1986

Address correspondence and reprint requests to Dr. Robert Fick, Division of Pulmonary Diseases, The University of Iowa Hospitals and Clinics, Iowa City, IA 52242 .

This work was supported by Research Advisory Group of the Veterans Administration and Grant RR59 from the General Clinical Research Centers Branch, National Institutes of Health. R.B.F. is the recipient of a Clinical Investigator Award (HL-0 1065) from the National Heart, Lung, and Blood Institute and a Cystic Fibrosis Foundation Research Grant.

${ }^{1}$ Parts of this work were presented at the American Society for Clinical Investigation annual meeting May 4-7, 1984 and the American Thoracic Society meeting May 20-23, 1984. Abstracts have appeared in Clin Res 132:428A, 1984, and Am Rev Respir Dis 129:18, 1984. and the proteolysis of radiolabeled C5 substrate was not prevented by inhibitors of neutrophil elastase. Although the purified metalloelastase of Pseudomonas aeruginosa was active on cell-bound and free $\mathrm{C} 5$ yielding $\mathrm{C5a}$, inhibition of this bacterial protease in CF lung fluids only partially blocked cleavage of the $\alpha$ - and $\beta$-chains of C5. Simultaneous inhibition of the serine and metalloprotease activities of $\mathrm{CF}$ lung fluids effectively blocked the in vitro generation of C5a leukocyte chemotactic activity. We conclude that $\mathrm{CF}$ lung fluids contain markedly increased levels of elastolytic activity which are closely linked to the extent of CF lung disease and which are capable of proteolytically generating $\mathrm{C5a}$. Both a serine proteinase and a metalloenzyme in these lung fluids contribute to the nonimmunologic generation of C5a. (Pediatr Res 20: 1258-1268, 1986)

\section{Abbreviations}

BAL, bronchial-alveolar lavage

BSA, bovine serum albumin

CF, cystic fibrosis

cpm, counts per minute

DTT, dithiothreitol

EDTA, ethylene diamine tetraacetic acid

FEF 25-75\%

expiratory flow determined between 25 and $75 \%$ of vital capacity

$F E V_{i}$, volume in liters expired in one second of a forced expiratory maneuver

$\mathrm{FEV}_{1} \%, \mathrm{FEV}_{1}$ expressed as a percentage of $\mathrm{FVC}$

FVC, vital capacity determined from a forced expiratory maneuver

HEPES, N-2-hydroxyethylpiperazine-N-2-ethane-sulfonic acid

Leu, leupeptin

PAGE, polyacrylamide gel electrophoresis

PM, pulmonary macrophages

PI, protease inhibitor

PMN leukocytes, polymorphonuclear leukocytes

PMSF, phenylmethylsulfonylfluoride

Pseudomonas, particular species Pseudomonas aeruginosa

RIA, radioimmunoassay

$R V$, residual volume

STI, soybean trypsin inhibitor

TCA, trichloroacetic acid

TLC, total lung capacity

TP, total protein

TPCK, L-1-tosylamide-2-phenyl-ethylchloromethyl ketone

Tris-HCl, hydroxymethylaminomethane buffer

ZAS, zymosan-activated serum 
Chronic pulmonary infection develops in the vast majority of patients with $\mathrm{CF}$, frequently dominating the clinical picture and determining the fate of the majority. Particularly prominent early pathologic lesions are bronchiolitis, plugging of airways by inflammatory cells and secretions, acute peribronchiolar inflammation and bronchiectasis (1). Destruction of respiratory bronchioles and alveolar ducts leads to connective tissue deposition and interstitial fibrosis with the consequence that greater than $90 \%$ of these patients die of progressive pulmonary insufficiency. Inflammatory secretions obtained from the lungs of patients with CF contain extraordinarily elevated levels of the neutral protease, elastase (2). Most of this elastolytic activity presents the inhibition profile of a serine proteinase, suggesting that it is derived from neutrophils which are present in the airways. It is generally accepted that such elastases contribute to the genesis of a destructive lung lesion (3). Additional affects of these elastases may be to further amplify the inflammatory process by generating neutrophil chemotactic activity by limited cleavage of C5 (4).

The proteins of the complement system play a major biologic role as mediators of inflammation and opsonization. Despite recurrent and recalcitrant bacterial infections of the lung and the nature of the destructive lung lesion in cystic fibrosis, no consistent alterations in serum complement levels have been documented (5). More recent studies have concluded that there is a uniform absence of $\mathrm{C} 3$ activation in CF sera (6), however, there is a paucity of information about the activation of complement proteins in vivo in $\mathrm{CF}$ airways.

The purpose of this study was to determine if biochemical and functional evidence of complement activation was present in fresh lung secretions obtained from CF patients, and to relate these activities to impairment of lung function. We also explored the relationship between proteases present in these biologic fluids and the nonimmune generation of functional polypeptide fragments of complement proteins.

\section{METHODS}

Experimental specimens and bronchial-alveolar lavage. Bronchial washings were performed on nine patients with CF (seven male, two female) with a mean age of $19 \mathrm{yr} \pm 5 \mathrm{SD}$ (range 12$31 \mathrm{yr}$ ). Eight of the CF patients had chronic colonization of their sputa with Pseudomonas aeruginosa but they were clinically stable and had not experienced a recent exacerbation of their lung disease. Quantitative cultures of homogenized, serially diluted sputa specimens employing selective and enriched media (7) had been routinely obtained from each of the CF patients. In brief, immediately following rinsing of the mouth with water sputum was collected into sterile containers, placed on ice, and transported to the microbiology laboratory within $20 \mathrm{~min}$. Equal volumes of sputum and $2 \% \mathrm{~N}$-acetylcysteine in PBS were mixed in sterile, thick-walled tubes containing acid-cleaned glass beads. The specimen was homogenized and serial 10-fold dilutions in PBS were prepared. Both selective and nonselective media are plated.

Lung lavages were performed on five normal healthy subjects (three male, two female) with a mean age of $23 \mathrm{yr} \pm 4 \mathrm{SD}$ (range 16-27 yr). None of these subjects smoked tobacco. These normal controls had no history of previous Pseudomonas infections and had not recently experienced respiratory infections. Blood was obtained from these 14 experimental subjects, serum was immediately separated by centrifugation at $4^{\circ} \mathrm{C}$ and stored at $-78^{\circ}$ C. Lung lavage to obtain respiratory secretions from $\mathrm{CF}$ patients and control subjects was performed and the fluids were processed as previously reported $(8-10)$. The volume of the lung lavage fluid from each subject was recorded and split into two portions: to one aliquot both $\mathrm{NaN}_{3}$ and EDTA were added to final concentrations of $0.01 \%(\mathrm{w} / \mathrm{v})$ and $10 \mathrm{mM}$, respectively. The second aliquot was not treated with EDTA. Total protein levels were determined by the method of Coomassie brilliant blue absorbance (11). The fluid was concentrated 10 -fold at $4^{\circ} \mathrm{C}$ using positive pressure ultrafiltration (Diaflo YM5 membrane, Amicon
Corp., Scientific Systems Div., Lexington, MA). The concentrated BAL fluid was then frozen at $-78^{\circ} \mathrm{C}$ until used in the assays to determine proteolytic and chemotactic activities and levels of complement components.

Clinical scoring and extent of lung disease. The CF patients selected for this study had been longitudinally followed for at least 3 yr by the staff of the University of Iowa Cystic Fibrosis Center. These patients were interviewed and examined in the CF center on a regular basis, not less frequently than at 6-month intervals. Chest radiographs were obtained annually; quantitative cultures of sputum and pulmonary function testing were performed at each visit. Spirometry was performed with a Med Science spirometer (Med Science Electronics, Inc., St. Louis, $\mathrm{MO}$ ) and $\mathrm{FEV}_{1} \%$ and FEF $25-75 \%$ were recorded from the spirometry (12). Lung volumes were determined in a pressure plethysmograph (model 2000, Cardio-Pulmonary Instrument Corp., Houston, TX) by a standard technique (13) and data were transmitted to a Tektronic computer (model 4052). The predicted values by the methods of Polgar and Promadhat (14) and Nelson et al. (15), the measured values, and flow-volume curves were automatically computed and recorded (Tektronix 4631). Chest radiographs and clinical pulmonary disease were scored using the scoring system originally proposed by Taussig et al. (16) and later modified (17). Interpretation of radiographs was performed in a blinded fashion noting degree of pulmonary markings, mucus plugging, over aeration, cyst formation, and the presence or absence of acute infiltrates. Parameters important to the calculation of pulmonary clinical scores included vital capacity and $\mathrm{FEV}_{1}$, recent relapses, a history of pneumothorax, hemoptysis, or cor pulmonale.

Enzyme assays. Elastolytic activity in the BAL fluids was measured by modification of a standard method $(2,9)$ using a microtube technique and ${ }^{14} \mathrm{C}$-labeled soluble elastin as the substrate. Soluble elastin substrate was prepared from bovine neck ligament elastin (Sigma, St. Louis, MO) by partial elastolysis in the presence of SDS using the method of Hall and Czerkawski (18). It was then labeled with ${ }^{14} \mathrm{C}$-formaldehyde by reductive alkylation using sodium cyanoborohydride and the technique of Dottavio-Martin and Ravel (19). This method provided soluble elastin with radioactivity $25,000-35,000 \mathrm{cpm} \cdot \mathrm{mg}^{-1}$. Porcine pancreatic elastase (Sigma type III, $120 \mathrm{U} \cdot \mathrm{mg}^{-1}$ solid) was used as the standard. A working substrate solution was prepared containing $0.5 \mathrm{mg} \cdot \mathrm{ml}^{-1}$ soluble elastin unlabeled carrier in 0.1 $\mathrm{M}$ Tris- $\mathrm{HCl}$ buffer $\mathrm{pH} 8.8$, and a minimum of ${ }^{14} \mathrm{C}$-labeled soluble elastin was added to give a final radioactivity of approximately $10,000 \mathrm{cpm} 100 \cdot \mu \mathrm{l}^{-1}$.

Labeled substrate mixture $(100 \mu \mathrm{l})$ was dispensed into all tubes followed by $100 \mu \mathrm{l} 0.1 \mathrm{M}$ Tris- $\mathrm{HCl}$ buffer. One hundred $\mu \mathrm{l}$ of similar calcium-containing buffer $(0.05 \mathrm{M}$ Tris- $\mathrm{HCl}, 0.005 \mathrm{M}$ $\mathrm{CaCl}_{2}, 0.2 \mathrm{M} \mathrm{NaCl}$, pH 7.4) were then dispensed into all tubes followed by $100 \mu \mathrm{l}$ elastase standards $\left(10-1000 \mathrm{ng} \cdot 100 \mu \mathrm{l}^{-1}\right.$ calcium buffer) or BAL samples in duplicate to be tested for elastolytic activity. Tubes were capped, mixed well, incubated in a water bath at $37^{\circ} \mathrm{C}$ for $18-24 \mathrm{~h}$ and the reaction was stopped by cooling to $0^{\circ} \mathrm{C}$ in an ice bath for $20 \mathrm{~min}$. One hundred $\mu \mathrm{l}$ cold $2 \%(\mathrm{w} / \mathrm{v})$ bovine serum albumin in $0.1 \mathrm{M}$ Tris- $\mathrm{HCl}$ buffer pH 8.8 were then added to each tube as a protein carrier, followed by $100 \mu \mathrm{l}$ cold $30 \%(\mathrm{v} / \mathrm{v})$ TCA. The tubes were capped and mixed and allowed to stand on ice for $15 \mathrm{~min}$. Undigested elastin substrate was then removed by centrifugation at $12,000 \times g$ (Beckman Microfuge 12) for 3 min. Supernates were mixed with $10 \mathrm{ml}$ scintillation cocktail (Ready-Solv HP, Beckman, St. Louis, $\mathrm{MO}$ ) and counted in a scintillation counter (Beckman LS 6800) for 5 min each.

Enzyme inhibition studies. For elastolytic activity inhibition studies test samples $(100 \mu \mathrm{l})$ or enzyme standards were preincubated for $30 \mathrm{~min}$ at $37^{\circ} \mathrm{C}$ with $100 \mu \mathrm{l}$ of an inhibitor in $0.1 \mathrm{M}$ Tris- $\mathrm{HCl} \mathrm{pH} 8.8$ and $100 \mu \mathrm{l}$ calcium-containing buffer $\mathrm{pH} 7.4$, prior to the addition of $100 \mu$ labeled elastin substrate mixture The assay was then performed as usual. Inhibitors were used at the following final assay concentrations: $\alpha$-1-proteinase inhibitor 
$\left(\alpha-1\right.$-PI, $\left.0.25 \mathrm{mg} \cdot \mathrm{ml}^{-1}\right) \mathrm{STI}\left(1 \mathrm{mg} \cdot \mathrm{ml}^{-1}\right)$, PMSF $(1 \mathrm{mM})$, phenanthroline $(1 \mathrm{mM})$, phosphoramidon $(0.06 \mathrm{mM})$, EDTA $(50$ $\mathrm{mM})$, and Leu (1 $\mathrm{mM})$. The serine protease inhibitors $\alpha-1-\mathrm{PI}$, STI, and PMSF are used to inhibit proteases most frequently arising from neutrophils; the metalloprotease inhibitors, phenanthroline, phosphoramidon, and EDTA are known to block the activity arising from $P$. aeruginosa and, in part, pulmonary macrophages; Leu inhibits another class of proteolytic enzymes, the thioproteases, including collagenase, papain, and the cathepsins. In all cases the final assay volume was $400 \mu$, the final assay $\mathrm{pH}$ of the two mixed buffers was 8.4 and the final calcium concentration was $2.5 \mathrm{mM}$. Results were graphed and expressed as ng porcine pancreatic elastase equivalent per $1 \mu \mathrm{g}$ protein in the sample tested. Protein was estimated by the Lowry method using bovine serum albumin as the protein standard.

Complement studies. Sera specimens, preserved at $-78^{\circ} \mathrm{C}$, were thawed and immediately applied in the assays measuring $\mathrm{C} 3$ and $\mathrm{C} 3 \mathrm{c}$. Serum C3 levels were determined by means of the radial immunodiffusion technique of Mancini et al. (20). The level of $\mathrm{C} 3$ in concentrated EDTA-treated bronchial-alveolar lavage fluid was assayed by rocket immunoelectrophoresis and was expressed as percent of BAL total protein. The C $3 \mathrm{c}$ fragments in both sera and BAL fluids were determined by the standard method of crossed-immunoelectrophoresis (21) employing $1 \%$ agarose containing a 1:5000 dilution of goat $\mathrm{IgG}$ antihuman C3 (Atlantic Antibodies, Westbrook, ME). Fresh normal human serum and ZAS were used as controls. The percentage of $\mathrm{C} 3 \mathrm{c}$ was determined by measuring the area under the $C 3 \mathrm{c}$ peak and dividing by the sum of the area under the $\mathrm{C} 3$ and $\mathrm{C} 3 \mathrm{c}$ peaks.

The C5 component of complement was isolated from normal human serum by a modification of the methods of Tack and Prahl (22) and then this protein was employed in the cleavage and polyacrylamide gel electrophoresis experiments detailed below. C5a was determined by means of a radioimmunoassay (Upjohn Diagnostics, Kalamazoo, MI) following the methods of Hugli and Chenoweth (23). The useful range of this assay is from $10 \mathrm{ng} \cdot \mathrm{ml}^{-1}$ to $400 \mathrm{ng} \cdot \mathrm{ml}^{-1}$. Specimens giving values $\geq 400 \mathrm{ng}$. $\mathrm{ml}^{-1}$ were diluted and the assay was repeated.

Neutrophil chemotaxis. The presence of a chemotactically active factor in BAL was assessed with the in vitro assay of Gallin et al. (25) employing ${ }^{51} \mathrm{Cr}$-labeled granulocytes. Fresh BAL specimens with $10 \mathrm{mM}$ EDTA from CF patients and normal subjects were adjusted to a uniform protein concentration $\left[1 \mathrm{mg} \cdot \mathrm{ml}^{-1}\right.$, placed in the lower well of a blindwell chemotaxis chamber (Neuro Probe, Inc., Bethesda, MD)] and assayed in triplicate. Two hundred $\mu \mathrm{l}$ of the ${ }^{51} \mathrm{Cr}$-tagged PMN leukocyte cell suspension were separated from $125 \mu \mathrm{l}$ of a chemotactic stimulus or control buffer by two filters in a blindwell chemotaxis chamber. The lower chemotaxis filter was $3 \mu \mathrm{m}$ nitrocellulose (MembraFil, Nucleopore Corp., Pleasanton, CA) and the upper filter directly in contact with the ${ }^{51} \mathrm{Cr}-\mathrm{PMN}$ leukocyte cell suspension was $5 \mu \mathrm{m}$ polycarbonate (Nucleopore Corp.). The chambers were incubated $\left(37^{\circ} \mathrm{C}\right.$, humidified air and $\left.5 \% \mathrm{CO}_{2}\right)$ for $1 \mathrm{~h}$ and the experiment was terminated by aspirating the cell suspension and discarding the upper (polycarbonate) filter. The lower (nitrocellulose) filter was rinsed in cold $0.9 \%$ saline, and counted in a $\gamma$ counter (model 5500, Beckman Instruments, Inc., Palo Alto, CA).

ZAS served as the positive chemotaxin and was prepared by incubating fresh serum in the presence of zymosan particles (Difco Laboratories, Detroit, MI) and diluting to 5\% using a standard method (26). Previous experiments with this assay showed that $5 \%$ ZAS yielded maximal chemotaxis. For these studies 1:2 dilution of 5\% ZAS resulted in half maximal (ED50) values (1170 corrected counts at $5 \%$ versus $527 \mathrm{cpm}$ at 1:2). Similarly, all concentrated CF BAL samples were used at maximal activities: $1: 1$ or $1: 2$ dilutions yielded counts similar to 1 ED50 U of 5\% ZAS. Chemotaxis was calculated by subtracting the cpm in the buffer control filters from the cpm in the experimental filters and dividing that number by the cpm in the positive control (ZAS) filter; results were expressed as a percentage.
The in vitro generation of additional chemoattractant activity from $\mathrm{C} 5$ by $\mathrm{CF}$ lung fluids was sought. In these experiments concentrated whole $\mathrm{CF}$ BAL specimens containing known amounts of a chemotaxin and, in some cases, inhibitors of metalloproteinases, serine proteases, or thioproteases were incubated at $37^{\circ} \mathrm{C}$ for $15 \mathrm{~min}$ with unlabeled C5 substrate. The chemoattractant activity in these lung secretions was then reassessed and results were expressed as a percent of the positive control, ZAS.

Column chromatography. The molecular weight of a chemotactically active factor present in CF lung fluids was determined by means of gel filtration chromatography. Fresh BAL fluids were prepared with $10 \mathrm{mM}$ EDTA and concentrated as described above. The BAL samples were applied in a volume equal to $1-4 \%$ of the gel bed volume on a column of polyacrylamide and agarose gel matrix (AcA 54 in $1.6 \mathrm{~cm} \times 40 \mathrm{~cm}$ column, LKB, Bromma, Sweden). The presence of a chemotactic substance was identified by employing eluate fractions in the chemotactic assay described above. Previously, a molecular weight calibration curve had been prepared by measuring the elution volumes of several standard proteins under identical running conditions. Calibration proteins were obtained from Sigma Chemical Co. and included: human serum albumin $(68,000 \mathrm{D})$, ovalbumin $(48,000$ D), $\alpha$-lactalbumin (14,200 D), cytochrome C (12,400 D), and bovine insulin $(5,000 \mathrm{D})$.

$P A G E$ and autoradiography. Methods designed to document the ability of CF BAL fluids to generate additional chemotactic activity from C5 substrates were described in "Neutrophil chemotaxis." The ability of CF BAL fluids to proteolytically generate additional amounts of $\mathrm{C} 5 \mathrm{a}$, the chemotactically active component of complement proteins, was demonstrated in vitro using the technique of autoradiography and protease inhibitors. The C5 was radiolabeled with Hunter-Bolton reagent (27) and extensively dialyzed against phosphate-buffered saline to remove unbound radiolabel. ${ }^{125} \mathrm{I}-\mathrm{C} 5(25,000 \mathrm{dpm})$ was added to $40 \mu 1$ of each CF and normal BAL fluid specimen and incubated for 15 min at $37^{\circ} \mathrm{C}$.

In an attempt to identify the source of this proteolytic activity, selected CF BAL specimens were incubated at $37^{\circ} \mathrm{C}$ for $30 \mathrm{~min}$ in the presence of protease inhibitors EDTA, PMSF, $\alpha-1-\mathrm{PI}$, and Leu (see "Enzyme inhibition studies") prior to the addition of radiolabeled $\mathrm{C} 5$ substrate. PAGE were utilized to identify $\mathrm{C5}$ cleavage $(2,28)$. Samples were applied to $7.5 \%$ or $10 \%$ SDSpolyacrylamide gels after reduction with $0.1 \mathrm{M}$ DTT. Normal human plasma and human serum albumin were used as carrier proteins. Electrophoresis was performed at $45 \mathrm{~mA}$ constant current per slab for $2.75 \mathrm{~h}$. The gels were dried on filter paper and autoradiography performed for $48 \mathrm{~h}$ at $-70^{\circ} \mathrm{C}$ using X-AR2 film (Kodak, Inc., Rochester, NY). C5a was identified by comparison of the electrophoretic migration of CF BAL-derived C5 fragments with $\mathrm{C} 5 \mathrm{a}$ standards purified from trypsin digested $\mathrm{C} 5$ and with $12.4 \mathrm{KD}$ purified cytochrome C.

Enzymic activity in lung fluids producing C5a. The nature of the enzymic activity in CF BAL fluids producing C5a by the limited proteolysis of $\mathrm{C} 5$ was investigated by employing recognized inhibitor compounds of the serine protease released from PMN leukocytes ( $\alpha$-1-PI, PMSF, STI), inhibitors of the metalloproteinase of Pseudomonas (EDTA, phenanthroline, phosphoramidon) and a thioprotease inhibitor (Leu). In a protocol similar to the "PAGE and autoradiography" experiments discussed immediately above, these protease inhibitors were added to lung fluids of three $\mathrm{CF}$ patients prior to the addition of $\mathrm{C} 5$ substrate. However, the amount of C5a generated was measured, not by PAGE but in a specific radioimmunoassay and the results were expressed as both C5a produced (ng) and the percent of inhibition of $\mathrm{C} 5 \mathrm{a}$ production.

$$
\text { Inhibition }(\%)=\frac{\text { C5a buffer }-\mathrm{C} 5 \mathrm{a} \text { inhibitor }}{\mathrm{C} 5 \mathrm{a} \text { buffer }} \times 100 \%
$$

Limited proteolysis of C5 by purified Pseudomonas elastase. The neutral metalloenzyme with elastolytic activity was purified 
from clinical isolates of $P$. aeruginosa by the methods of Morihara et al. (24). In brief, bacteria suspensions were sonicated, centrifuged to remove bacterial cell wall debri, and dialyzed extensively against $0.01 \mathrm{M}$ Tris- $\mathrm{HCl}, 0.5 \mathrm{mM} \mathrm{CaCl}_{2}, \mathrm{pH} 7.5$. The dialyzed solutions were applied to a series of DEAE-cellulose (Whatman, Maidstone, UK) columns. The active fractions were pooled and concentrated by positive pressure ultrafiltration (UM 10 membrane, Diaflo, Amicon). The bacterial enzyme isolated was characterized by a single band on PAGE and a high specific activity in an assay employing soluble ${ }^{14} \mathrm{C}$-labeled elastin substrate (see above). Purified C5 substrate vide supra was added to increasing concentrations of this purified bacterial enzyme and incubated at $37^{\circ} \mathrm{C}$ for $30 \mathrm{~min}$. EDTA $(50 \mathrm{mM})$ was used to inhibit the reaction prior to measuring the quantity of $\mathrm{C} 5 \mathrm{a}$ produced in a RIA.

Cell-associated $C 5$ and generation of chemotactic activity and $\mathrm{C} 5 \mathrm{a}$. The experiments detailed above examined the effect of CF BAL fluids, with and without protease inhibitors, and purified Pseudomonas elastase on isolated C5. Because it has been suggested that pulmonary macrophages may synthesize C5 (29), we examined the influence of $\mathrm{CF}$ BAL fluids and the bacterial elastase on the release of C5a from normal human PM and the production of chemotactic factor(s) for neutrophils. PM were obtained from healthy normal nonsmoking volunteers who underwent transoral flexible fiberoptic bronchoscopy and lung lavage as described above. The lavage fluid cell pellet $(93 \%$ macrophages, $7 \%$ lymphocytes) was then processed in a standard fashion for short-term cell cultures $(2,8,10,26)$. Sixteen hours later, culture media was removed and replaced with $1 \mathrm{ml}$ aliquots of CF lavage fluid $(n=5)$, lavage fluid specimens from normal volunteers $(n=4)$, and CF BAL fluid specimens with added PMSF (1 mM) or EDTA (50 mM).

To evaluate the production of chemotactic activity these PM monolayers were incubated at $37^{\circ} \mathrm{C}$ in $5 \% \mathrm{CO}_{2}$ with humidified air for $60 \mathrm{~min}$. PM monolayer supernatants were then placed in duplicate in blindwell chemotaxis chambers and chemotaxis was evaluated in a leading front assay as previously described (30). Results were expressed as corrected cells $\cdot \mathrm{hpf}^{-1}$ : Corrected cells/ $\mathrm{hpf}=$ cells/hpf (stimulus) - cells/hpf (buffer salt solution). Results were compared to directed movement in response to $10 \%$ lipopolysaccharide-activated serum. In order to determine if chemotactic activity was attributable to C5a equal volumes of supernatants from cultures of PM were incubated with Fab fragments of anti-C $5 \mathrm{a}$ antibody $\left(1 \mathrm{mg} \cdot \mathrm{ml}^{-1}\right)$ raised in rabbits to human $\mathrm{C} 5 \mathrm{a}$ and the assay for chemotactic activity was then repeated.

In addition, normal human $\mathrm{PM}$ were incubated at $37^{\circ} \mathrm{C}$ for $30 \mathrm{~min}$ in the presence of selected concentrations of purified elastase from $P$. aeruginosa. Enzyme activity was inhibited at the end of the incubation period with the addition of EDTA to a final concentration of $50 \mathrm{mM}$. The assay tubes were centrifuged at $2000 \times g$ for $3 \mathrm{~min}$ to pellet cells and the supernatants were assayed for C5a by a competitive radioimmunoassay (Upjohn Diagnostics). Results are expressed as C5a produced (ng) per $10^{6}$ cells or per ml supernatant.

Statistical methods. Arithmetic means and SDs of the cell differential counts, levels of elastolytic activity, and the complement components in BAL specimens were calculated and analyzed by Student's $t$ test for compared data. $p$ values reported are for a two-tailed test. The relationships of protein and protease values to clinical parameters (age, lung function, Pseudomonas colony counts, clinical scores) were determined by multivariant analysis employing standard regression equations. The correlation coefficients reported are partial correlation coefficients with the controlled variables defined. Standard error of estimate, Pearson's correlation coefficients, and the F ratio were used to evaluate these data.

\section{RESULTS}

Overview. It was hypothesized that free chemotactic activity for PMN leukocytes is present at elevated levels in CF airway fluids and that airway proteases nonimmunologically generate C5a chemotactic activity. In order to support these hypotheses the levels of chemotactic and elastolytic activities were measured and the identity of the chemotaxin was sought. It was reasoned that the generation of additional chemotactic activity after adding C5 substrate to $\mathrm{CF}$ airway fluids supported the notion that chemotaxin-generating activity existed in these biologic fluids. Finally, the proteases yielding chemotactic C5a polypeptides from cell-bound and free C5 proteins were characterized.

Lung lavage fluid elastolytic activity and cell differential. Fluid return from $\mathrm{CF}$ patients during the lung lavage procedure was uniformly greater than $55 \%$ of that instilled, attaining a mean of $122 \mathrm{ml} \pm 10(\mathrm{SD})$. This value of fluid return did not differ in a statistically significant fashion when compared to healthy normal subjects. The levels of elastolytic activity in CF BAL fluids (17.7 $\mathrm{ng} \cdot \mu \mathrm{g} \mathrm{TP}{ }^{-1}$, range $0.72-62.4 \mathrm{ng} \cdot \mu \mathrm{g} \mathrm{TP}^{-1}$ ) were significantly elevated when compared to levels in BAL fluids obtained from normal volunteers $\left(0.2 \mathrm{ng} \cdot \mu \mathrm{g} \mathrm{TP}{ }^{-1}, p=0.001\right)$ as previously reported (2). Although the elastolytic activity present in respiratory secretions of healthy control subjects is largely a metalloproteinase ( $87 \%$ mean inhibition by $50 \mathrm{mM}$ EDTA) $(9,31), 83 \% \pm$ $8 \mathrm{SD}$ of the elastolytic activity in CF lung fluids had the inhibition profile of a serine proteinase (inhibited by $1 \mathrm{mg} \cdot \mathrm{ml}^{-1}$ soybean trypsin inhibitor). Additionally, CF BAL fluid elastase was $77 \%$ inhibited by $1 \mathrm{mM}$ PMSF (a serine protease inhibitor) and $19 \%$ inhibited by EDTA (a metalloproteinase inhibitor).

In the lung lavage fluids of normal volunteers it is unusual to find that PMN leukocytes comprise greater than 3\% of the respiratory cell pellet (32). Nevertheless, BAL fluids obtained from these stable CF patients contained 39\% \pm 16 SD PMN leukocytes. Numbers of PMN leukocytes present in CF lung fluids [mean $27 \pm 33\left(10^{5}\right) \cdot \mathrm{ml} \mathrm{lung}$ fluid ${ }^{-1}$ ] were directly related to the percent of elastolytic activity that was a serine protease (STI-inhibitable, $r=0.71, p=0.05$ ). Additionally, the total elastolytic activity present in $\mathrm{CF}$ lung secretions was positively correlated with the numbers of Pseudomonads cultured $(r=$ $0.81, p=0.03$, the numbers of PMN leukocytes controlled during the analysis) (Fig. 1).

Chemotactic activity present in CF lung secretions and in vitro generation of this activity from $C 5$. The chemotactic activity present in CF lung fluids and BAL fluids obtained from normal volunteers, each adjusted to a uniform protein concentration, are compared in Figure 2. A standard checkerboard experiment proved that this heightened cell mobility in response to CF lung fluids did indeed represent true chemotaxis in response to a chemical gradient and not simply heightened random movement (chemokinesis). Movement of the PMN leukocyte indicator cells into the chemotactic filter was inversely related to the percent (v/v) of diluted CF BAL added to the upper chamber. The CF

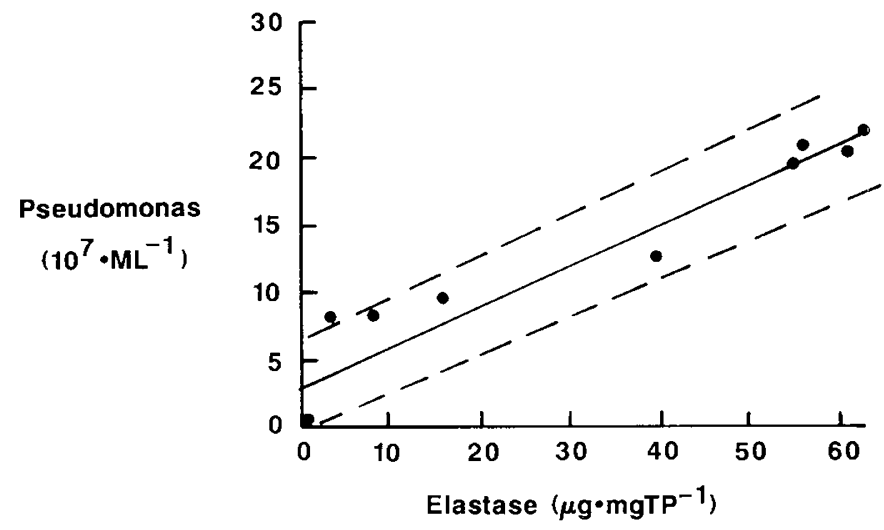

Fig. 1. Pseudomonas colonization of CF sputum and levels of elastolytic activity in bronchoalveolar lung lavage fluids. As the numbers of colony forming units of $P$. aeruginosa sputa samples (ordinate) increased, the concentration of elastase (relative to total protein) (abscissa) increased $(p=0.03)$. Ninety-five percent confidence intervals are given by the broken lines. 


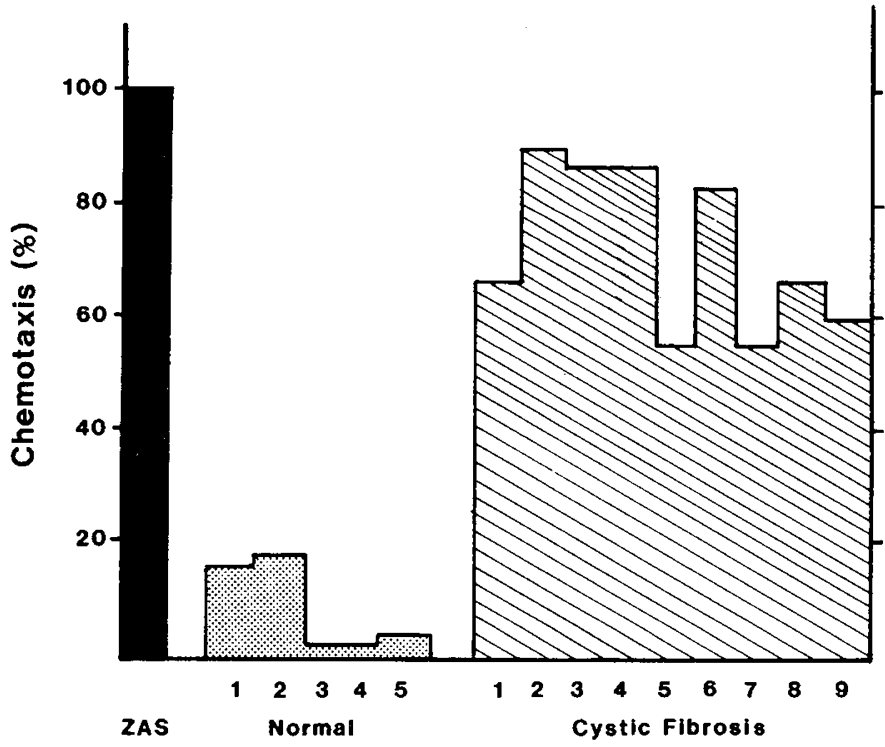

Fig. 2. Chemotactic activity present in lung lavage fluids obtained from CF patients $(n=9)$ and normal volunteers $(n=5)$ (abscissa). Specimens have been concentrated. $10 \mathrm{mM}$ EDTA was added and aliquots were applied to blindwell chemotactic chambers at a uniform concentration of total protein $\left(1 \mathrm{mg} \cdot \mathrm{ml}^{-1}\right)$. The ordinate represents ${ }^{51} \mathrm{Cr}$ labeled PMN leukocytes in cpm present in a $3 \mu \mathrm{M}$ nitrocellulose filter expressed as a percent of the cpm in the positive control, 5\% ZAS. Each bar represents the mean of three experiments.

patients with the lowest levels of relative chemotactic activity in BAL fluids (both $56 \%$ relative to ZAS control, Fig. 2) also contained the lowest elastolytic activities $(0.72$ and $0.88 \mathrm{ng} \cdot \mu \mathrm{g}$ $\mathrm{TP}^{-1}$ ).

Additional chemotactic activity could be generated in vitro by incubating $\mathrm{CF}$ BAL specimens of established chemotactic activities with exogenously applied C5 protein (Fig. 3). Chemotactic activity already present at significantly elevated levels in CF lung fluids was further augmented in the presence of additional C5 substrate, demonstrating the presence of substances in CF airway fluids which act on $\mathrm{C} 5$, generating a chemotaxin. BAL specimens obtained from normal volunteers did not contain this chemotaxin-generating activity because incubation with $\mathrm{C} 5$ did not result in the appearance of significant levels of leukotactic activity, $p>0.2$ (see Fig. 3).

Complement activation in vivo. Evidence for in vivo activation of the complement cascade was sought. Generation of the $\mathrm{C} 3 \mathrm{c}$ polypeptide fragment of $\mathrm{C} 3$ was present in some $\mathrm{CF}$ sera and all $\mathrm{CF}$ respiratory secretions (Table 1 ). Compatible with an earlier report (2) noting increased levels of $\mathrm{C} 3 \mathrm{c}$ determined by radial immunodiffusion in CF BAL are the observations that $\mathrm{C} 3$ levels are decreased in CF BAL (Table 1), and C3c determined by crossed immunoelectrophoresis (Fig. 4) is strikingly increased when compared to the values in respiratory secretions obtained from normal volunteers (Table 1). Such evidence of complement activation is not normally present in the sera and lung fluid of healthy subjects. Small peaks of $\mathrm{C} 3 \mathrm{c}$ were observed in the sera of three of the nine CF patients. The CF patients with measurable amounts of $\mathrm{C} 3 \mathrm{c}$ in serum $(4.18,4.33$, and $9.53 \%$ of serum $\mathrm{C} 3$ ) were those individuals with the highest BAL fluid C3c levels $(87$, 100 , and $100 \%$ of $\mathrm{C} 3$, respectively). The high degree of complement activation, represented by $\mathrm{C} 3 \mathrm{c}$, in $\mathrm{CF}$ lung fluids was directly related to: 1$)$ the numbers of PMN leukocytes present in these fluids $(p=0.002)$ and 2$)$ to total BAL elastolytic activity $(p=0.020)$.

Levels of $\mathrm{C} 5 \mathrm{a}$ polypeptide determined by RIA were also significantly increased in CF lung secretions $\left(258 \mathrm{ng} \cdot \mathrm{ml}^{-1} \pm 69\right.$ SEM, $n=7)$ when compared to normal volunteers $(<10 \mathrm{ng}$. $\left.\mathrm{ml}^{-1}, p<0.001\right)$. The highest levels of C5a (472 and $590 \mathrm{ng}$. $\mathrm{ml}^{-1}$ ) were found in those CF patients with the highest elastase

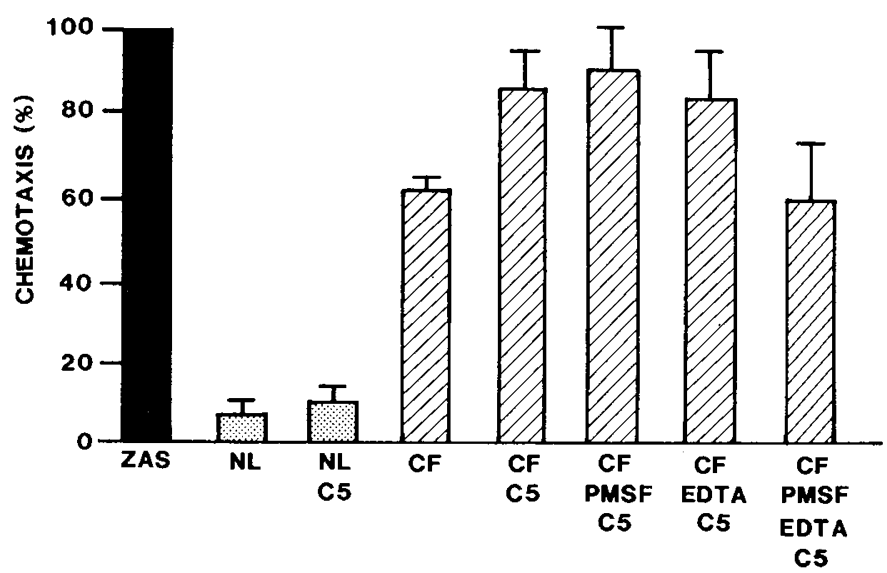

Fig. 3. Chemotaxin generating activity present in CF BAL fluids is represented in this bar graph displaying mean chemotactic activity present in lung fluids with and without C5 substrate added. Chemotaxis of ${ }^{51} \mathrm{Cr}$-labeled PMN leukocytes is expressed as percent \pm SEM of the positive control, ZAS (ordinate). Bronchial-alveolar lavage samples ( $a b$ scissa) obtained from normal volunteers $(N L, n=6)$ contained a low level of chemotactic activity which was not significantly increased by coincubation with $\mathrm{C} 5$ substrate, bar $3, p>0.2$. Lung lavage fluids from CF patients ( $C F$, bar $4, n=6$ ) displayed a significantly elevated level of chemoattractant activity ( $p=0.001, c p$ to $N L$, bar 2) which was increased further with the addition of $\mathrm{C5}$ ( bar $5, p=0.01, c p$ to $C F$, bar 4). Inhibitors have been employed (bars 6-8) in an attempt to better characterize the protease responsible for the cleavage of $\mathrm{C} 5$, generating chemotactic activity. The addition of the serine proteinase inhibitor PMSF (column 6) and the metalloproteinase inhibitor EDTA (column 7) did not significantly alter the percent chemotaxis. However, adding inhibitors of both serine proteases and metalloproteinases (column $8, n$ $=4$ ) caused a significant reduction in the chemotaxin-generating activity in CF BAL fluids: $\mathrm{CF}+\mathrm{PMSF}+\mathrm{EDTA}+\mathrm{C} 557 \% \pm 10.6$ versus $\mathrm{CF}+$ $\mathrm{C} 5$ (bar 5) $87 \% \pm 4.1, p=0.001 ; \mathrm{CF}+\mathrm{PMSF}+\mathrm{EDTA}+\mathrm{C} 5$ versus $\mathrm{CF}$ (bar 4) $60 \% \pm 3.4, p>0.2$.

Table 1. C3 levels and complement activation

\begin{tabular}{llccc}
\hline \multirow{2}{c}{ Group $(n)$} & Source & $\begin{array}{c}\text { Total protein* } \\
(\mathrm{mg} / \mathrm{ml})\end{array}$ & $\begin{array}{c}\mathrm{C} 3 \dagger \\
(\mu \mathrm{g} / \mathrm{mg})\end{array}$ & $\mathrm{C} 3 \mathrm{c}(\%) \ddagger$ \\
\hline Normal subjects (5) & Serum & $80.6 \pm 19$ & $13.5 \pm 1.2$ & 0 \\
& BAL & $3.6 \pm 2$ & $6.6 \pm 2$ & 0 \\
& & & & \\
$\mathrm{CF}(9)$ & Serum & $53.2 \pm 3 \S$ & $18.6 \pm 1 \S$ & $2.6 \pm 1.3 \S$ \\
& BAL & $1.4 \pm 0.3$ & $4.1 \pm 2.9$ & $49 \pm 1.5 \S$ \\
\hline
\end{tabular}

* Determined by Coomassie brilliant blue absorbance and expressed as a mean value.

$\dagger$ Mean value expressed in $\mu \mathrm{g} /$ total protein $(\mathrm{mg}$ ).

$\ddagger \%$ of total $\mathrm{C} 3 \pm \mathrm{SD}$.

$\S p<0.01$ for comparable specimens, NL versus CF; $p<0.05$ for comparable specimens, NL versus $\mathrm{CF}$.

activities (Fig. 5). There was a direct relationship between the total elastolytic activity present in CF airways and the concentration of C5a $(r=0.97, p=0.03$, controlling for PMN leukocytes and Pseudomonas burden). Omitting the addition of $10 \mathrm{mM}$ EDTA to the fresh lung lavage fluids did not alter the percent $\mathrm{C} 3 \mathrm{c}$ or the concentration of C5a detected, suggesting these biologically important fragments were generated in vivo.

Identification of a chemotaxin in CF respiratory fluids. Chemotactic activity for neutrophils was found to be strikingly elevated in CF lung fluids (vide supra) but the identity of this chemotaxin was unknown. Therefore, fresh, concentrated, EDTA-treated lung fluids obtained from CF patients with known chemotactic activity (see above Fig. 2) were subjected to gel filtration chromatography. The chromatogram determined spectrophotomet- 

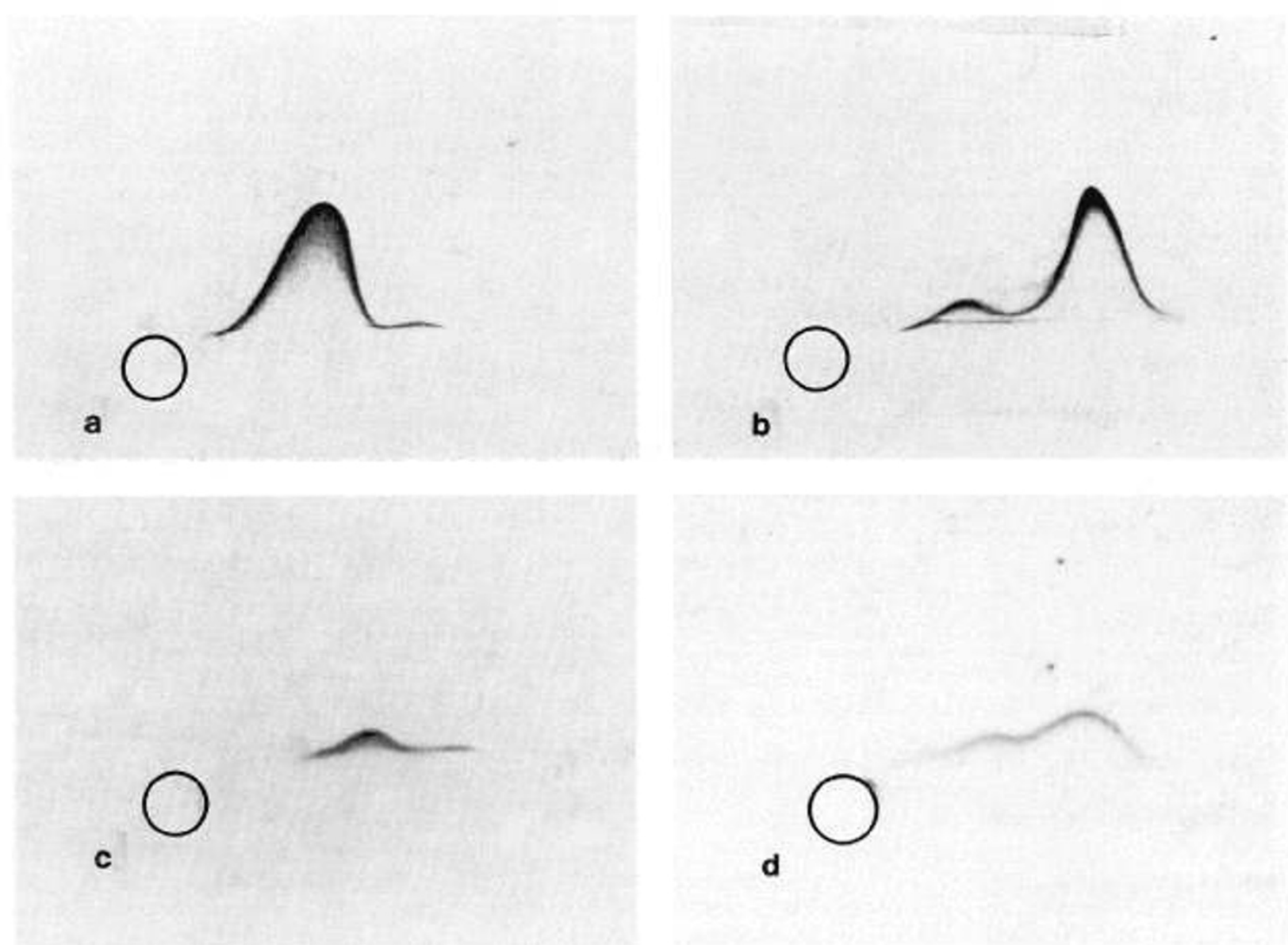

Fig. 4. Complement activation in $\mathrm{CF}$ lung fluids. A representative crossed immunoelectrophoresis demonstrating cleavage of $\mathrm{C} 3$ in $\mathrm{CF} B \mathrm{BA}$ fluid. Normal serum $(a)$ and BAL fluid from a healthy normal volunteer $(c)$ at equivalent protein concentrations have been placed into wells cut into agar and then electrophoresed. Normal serum contains a higher concentration of C3 than lung fluids from such normal volunteers. However, neither specimen contains cleavage products of $\mathrm{C} 3$. Fresh serum from a normal volunteer when activated by incubation in the presence of zymosan (b) results in activation of C3. A large second immunoprecipitin peak represents C3c. Similarly, activation of C3 in CF BAL fluid is demonstrated $(d)$.

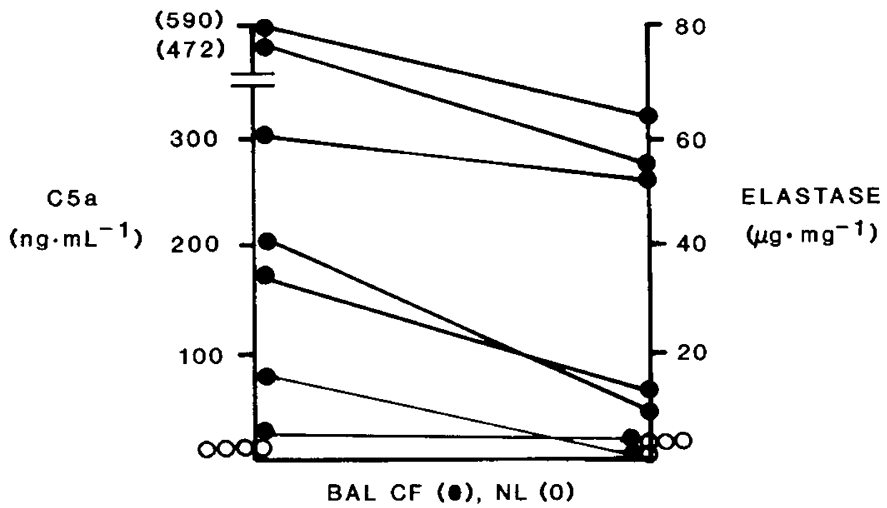

Fig. 5. Levels of the complement component C5a and elastolytic activity in BAL fluids of $C F$ patients $(\bullet)$ and normal volunteers $(O)$. The C5a polypeptide fragment of $\mathrm{C} 5$ was present in CF lung fluids and was not identified in BAL obtained from normal nonsmoking volunteers. Similarly, elastolytic activities were elevated in the CF fluids; elastolytic activity in normal BAL was uniformly less than $1 \mu \mathrm{g} \cdot \mathrm{mg}^{-1}$. CF patients with the highest concentrations of this proteolytic activity had the highest C5a levels; those with the lowest elastolytic activity also had the lowest levels of C5a polypeptide.

rically $\left(\mathrm{A}_{278}\right)$ reproducibly resulted in two peaks of absorbance (Fig. 6). The first peak of absorbance was at the void volume and represented substances with molecular weights of $68,000 \mathrm{D}$ and greater. The second, smaller peak of absorbance occurred at the end of the linear fractionation range for the acrylamideagarose gel matrix $(5000 \mathrm{D})$. Chemotactic activity was identified in the tubes collecting elution volumes 28 to $34 \mathrm{ml}$ (Fig. 6). During experiments to calibrate the column cytochrome $\mathrm{C}$ $(12,400 \mathrm{D})$ and $\alpha$-lactalbumin $(14,200 \mathrm{D})$ were reproducibly recovered at the same elution volumes. A sensitive RIA confirmed the identity of $\mathrm{C} 5 \mathrm{a}$ in these column fractions containing chemotactic activity.

Potential sources of the proteolytic activity which generates leukocyte chemotactic activity in lung fluids. The activity present in CF fluids which acted on $\mathrm{C} 5$ producing increased polymorphonuclear leukocyte chemotaxis (vide supra, Fig. 2) can be attributed to both serine and metalloproteases. Addition of PMSF (an inhibitor of neutrophil elastase) to CF lung fluids prior to the addition of C5 substrate (column 6, Fig. 3) did not ablate the chemotaxin generating activity. Similarly, the chelator EDTA, a metalloprotease inhibitor of Pseudomonas elastase, used in an identical fashion did not prevent an increase in chemotactic activity (Fig. 3, $61 \%$ in column 4 increased to $84 \%$ in column 7). Only by the simultaneous application of PMSF and EDTA could the chemotaxin-generating activity of CF BAL be successfully blocked (column 8 ).

Proteolytic generation of $C 5 a$ and potential sources of this proteolytic activity. Because $\mathrm{C} 5 \mathrm{a}$ was shown to be a major component of the chemotactic activity in CF BAL fluids, a mechanism generating this polypeptide was directly examined. Radiolabeled C5 was incubated with normal and CF BAL fluids, electrophoresed on $7.5 \%$ SDS-polyacrylamide gels and developed by autoradiography (Fig. 7). Lung lavage fluid from a normal 


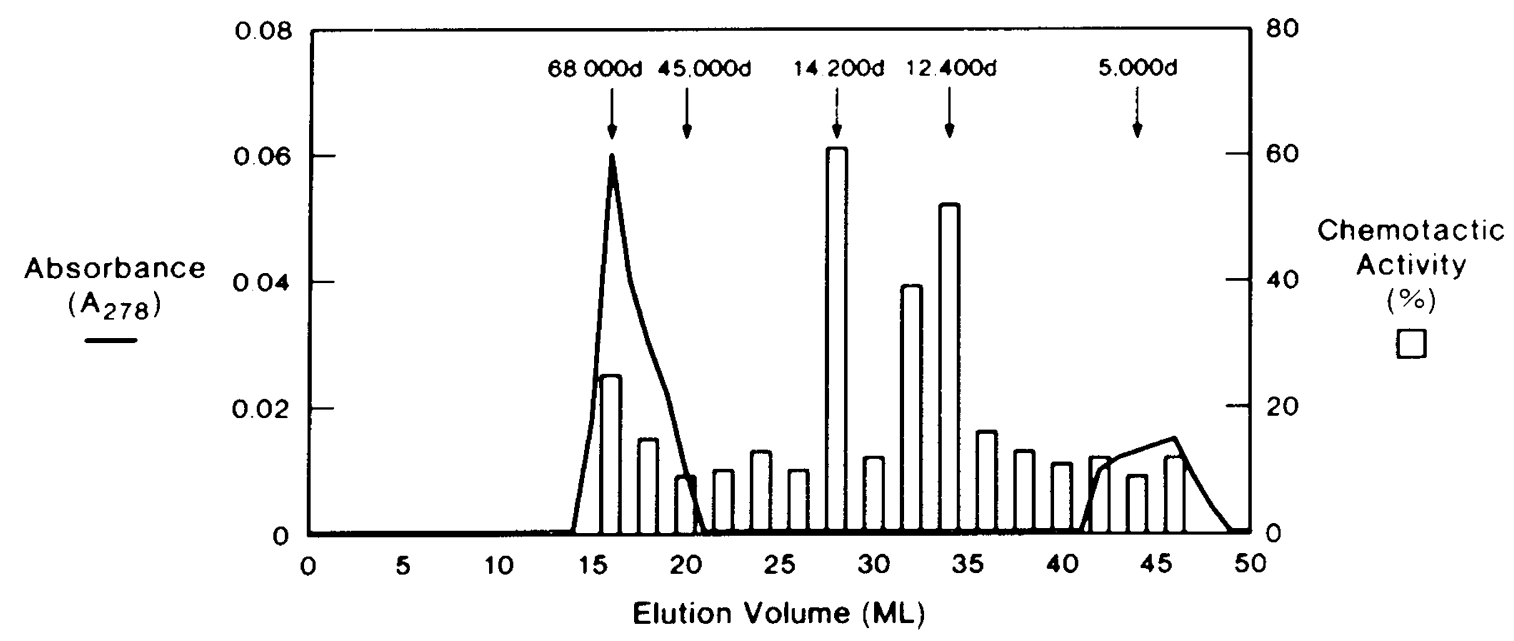

C5a levels $\left(\mathrm{Ng} \cdot \mathrm{ML}^{-1}\right)$

\begin{tabular}{|l|l|l|l|l|l|l|l|l|l|l|}
\hline 0 & 0 & 82 & 0 & 22 & 23 & 0 & 0 & 0 & 4 & 0 \\
\hline
\end{tabular}

Fig. 6. Characterization of the chemotactic substance present in CF lung lavage fluids. Shown are representative results of column chromatography in which concentrated, EDTA-treated CF respiratory secretions have been fractionated on AcA-54 acrylamide-agarose gel. This gel matrix has a void volume of $16 \mathrm{ml}$ and a linear fractionation of 5,000 D to $68,000 \mathrm{D}$ for globular proteins. Shown are the absorbance determined spectrophotometrically (left ordinate) and the elution volume (abscissa). The locations at which protein standards were eluted are indicated by arrows $(68,000 \mathrm{D}$ human serum albumin, 45,000 D ovalbumin, 14,200 D $\alpha$-lactalbumin, 12,400 D cytochrome C, and 5,000 D bovine insulin). Chemotactic activity determined by means of ${ }^{51} \mathrm{Cr}$-labeled neutrophils and expressed as percent of the positive control (right ordinate) was detected at elution volumes $28-34 \mathrm{ml}$. This is the elution volume at which proteins with molecular weights of $12,400 \mathrm{D}$ to $14,200 \mathrm{D}$ eluted. A specific RIA reproducibly identified antigenic $\mathrm{C} 5 \mathrm{a}$ in the same fractions (lower abscissa).

volunteer and human serum albumin served as negative controls with only the $\alpha$ and $\beta$ chains of C5 detectable in these experiments (Fig. 7, columns 1 and 2). In contrast, CF BAL resulted in a limited proteolysis of the alpha chain and the generation of a $12 \mathrm{KD}$ peptide fragment compatible with C5a (arrow, columns 3 and 4). This was most marked with the CF BAL fluids with the highest elastolytic activity, suggesting a proteolytic mechanism. Experiments designed to study the kinetics of C5 proteolysis in CF BAL fluids demonstrated insignificant differences in cleavage when $1 \mathrm{~min}$ of incubation was compared to $45 \mathrm{~min}$ of incubation at $37^{\circ} \mathrm{C}$. Trypsin $\left(0.3 \mu \mathrm{g} \cdot \mathrm{ml}^{-1}\right)$ digestion of reduced $\mathrm{C} 5$, known to produce the $\mathrm{C} 5$ a fragment, resulted in the same electrophoretic pattern as CF specimens shown in Figure 7, columns 3 and 4.

Inhibitors of the serine proteinase released from PMN leukocytes were employed in an attempt to delineate the source of this C5 proteolytic activity. PMSF and $\alpha$-1-PI did not ablate this activity (Fig. 7). In each case, $12,000 \mathrm{~mol}$ wt and smaller fragments resulted. Only by simultaneously blocking both serine and metalloproteases with EDTA and PMSF could the reduced C5 substrate be preserved and the generation of a $12 \mathrm{KD}$ polypeptide be blocked.

These observations were confirmed in a separate series of experiments in which $\mathrm{C} 5$ a levels were directly quantitated (Table 2 ). The serine protease inhibitors $\alpha-1-P I$, STI, and PMSF inhibited the generation of $\mathrm{C} 5 \mathrm{a}$ from $\mathrm{C} 5$ substrate in the presence of CF BAL specimens: mean $51 \% \pm 3.1$ inhibition, $59 \% \pm 4.1$, and $39 \% \pm 3.9$, respectively. Similarly, the metalloproteinase inhibitors phenanthroline, phosphoramidon, and EDTA resulted in inhibitions of $33 \pm 3.5 \%, 33 \pm 10 \%$, and $32 \pm 4.1 \%$, respectively. In contrast, the thioproteinase inhibitor, Leu, had little effect on C5a generation (Table 2): 3.03 to $4.14 \mathrm{ng}$ C5a were produced from $\mathrm{C} 5$ in the presence of CF BAL specimens and buffer salt solution control; a range of 3.02 to $3.93 \mathrm{ng}$ of $\mathrm{C} 5 \mathrm{a}$ resulted when Leu was added ( $1 \mathrm{mM}$ inhibits $92 \%$ of the proteolytic activity of $1 \mathrm{mM}$ papain).

CF lung fluids contain many potential sources of elastolytic activity. The elastase purified from $P$. aeruginosa was substituted for CF BAL specimens in the experiments above. In these studies purified C5 substrate was enzymically altered by the elastase produced by $P$. aeruginosa yielding fragments recognized as $\mathrm{C} 5 \mathrm{a}$ in a RIA (Table 3). As the amount of purified Pseudomonas elastase increased from 10 to $300 \mathrm{ng}$, C5a levels increased accordingly: $5.9 \mathrm{mg} \cdot \mathrm{ml}^{-1} \pm 0.3$ to $10.1 \mathrm{ng} \cdot \mathrm{ml}^{-1} \pm 1.8$.

Role of pulmonary macrophages in the production of $\mathrm{C5a}$ chemotaxins. Pulmonary macrophages possess $\mathrm{C} 5$ polypeptides attached to surface membranes (Robbins RA, Russ WD, Thomas $\mathrm{KR}$, Rasmussen J, Kay HD, unpublished data) and when stimulated are known to release chemotactic substances for neutrophils (10). In order to investigate the role PM might play in the generation of $\mathrm{C} 5 \mathrm{a}$ anaphylatoxins normal human PM were cultured in the presence of $\mathrm{CF}$ and normal BAL fluids and then supernatant fluids were assayed for chemotactic activity. CF BAL fluid specimens $(n=5)$ assayed in duplicate produced a leading front of $27 \pm 3.7$ cells. $\mathrm{hpf}^{-1}$ (corrected \pm SEM) and after incubation with macrophages CF BAL samples yielded chemotactic activity attracting $77 \pm 18$ cells $\cdot \mathrm{hpf}^{-1}$ (corrected). Controls in these experiments included $10 \%$ lipopolysaccharide-activated serum (mean $141 \pm 5$ cells $\cdot \mathrm{hpf}^{-1}$ ), lung lavage fluid from normal volunteers (mean $5 \pm 4.1$ cells $\cdot \mathrm{hpf}^{-1}$ ), and normal human PM cultured in lung lavage fluid from healthy normal volunteers (mean $15 \pm 2.6$ cells $\cdot \mathrm{hpf}^{-1}$ ). Addition of polyclonal serum against $\mathrm{C} 5 \mathrm{a}$ removed $66 \%$ of the chemotactic activity so that the leading front went from $77 \pm 18$ to $26 \pm 11$ cells $\cdot \mathrm{hpf}^{-1}$ after the addition of anti-C5a. When the serine and metalloproteinase inhibitors (PMSF 1 and EDTA $50 \mathrm{mM}$, respectively) were added to CF lung fluids, the generation of chemotactic activity was partially blocked: $\mathrm{PM}+\mathrm{CF}$ BAL $77 \pm 18$ cells $\cdot \mathrm{hpf}^{-1} ; \mathrm{PM}+\mathrm{CF}$ BAL + PMSF $51 \pm 12$ cells $\cdot \mathrm{hpf}^{-1} ; \mathrm{PM}+\mathrm{CF}$ BAL + EDTA 49 \pm 8 cells $\cdot \mathrm{hpf}^{-1}$ attracted.

It seems likely that the metalloproteinase of $P$. aeruginosa in $\mathrm{CF}$ airway secretions contributes to the generation of the C5a chemotactic activity released from PM. Purified bacterial elastase released $\mathrm{C} 5 \mathrm{a}$ from $\mathrm{PM}$ in a concentration and temperaturedependent fashion (Fig. 8). Normal human pulmonary macrophages released $38 \mathrm{ng} \cdot \mathrm{ml}^{-1} \mathrm{C} 5 \mathrm{a}$ after $30 \mathrm{~min}$ in the presence of $100 \mathrm{ng}$ of purified Pseudomonas elastase. Lowering the reaction temperature to room temperature $\left(22^{\circ} \mathrm{C}\right)$ significantly reduced the amount of C5a detected in the RIA.

Extent of lung disease. Others have noted the important rela- 


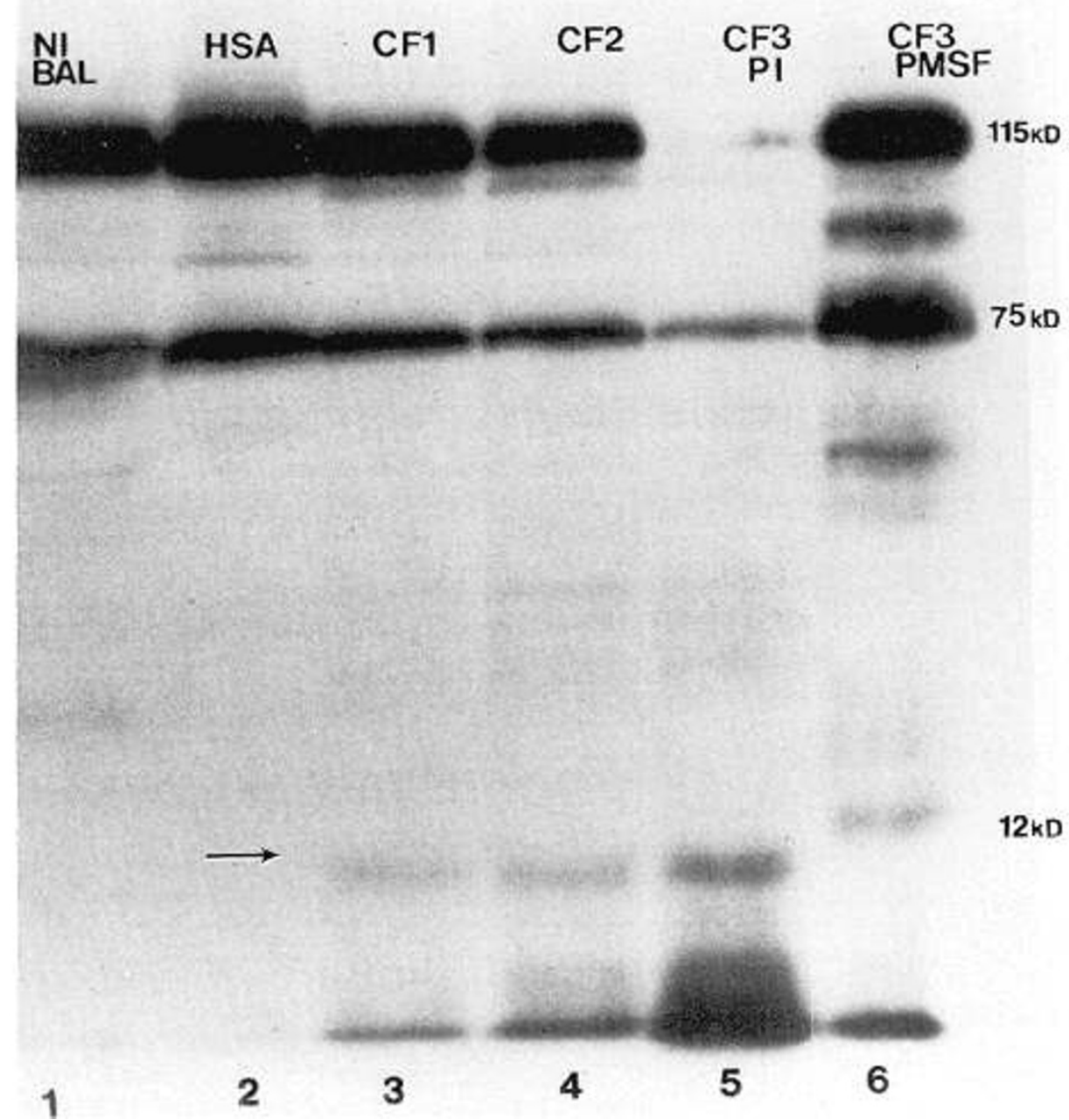

Fig. 7. In vitro cleavage of ${ }^{125} \mathrm{I}-\mathrm{C} 5$ substrate by CF BAL fluids is demonstrated on these autoradiographs of $7.5 \%$ sodium dodecyl sulfatepolyacrylamide gels. Dithiothreitol reduced and radiolabeled $\mathrm{C} 5$ has been added to each of the columns. The $\alpha-(115 \mathrm{KD})$ and $\beta$ - (75 KD) chains of the reduced $\mathrm{C} 5$ substrate are clearly shown in columns $I$ and 2 in which $\mathrm{C} 5$ has been incubated in the presence of BAL from a normal volunteer (column I) and $1.0 \mathrm{mg} \cdot \mathrm{ml}^{-1}$ human serum albumin (HSA, column 2). CF lung lavage fluids reproducibly resulted in the limited proteolysis of the $\alpha$-chain (columns 3 and 4 ) and the generation of a new $12 \mathrm{KD}$ molecular weight peptide (arrow). A third CF BAL specimen has been incubated with the radiolabeled and reduced C5 substrate in the presence of inhibitors of neutrophil proteinase. $\alpha-1-\mathrm{PI}\left(120 \mu \mathrm{g} \cdot \mathrm{ml}^{-1}\right)$ and PMSF $(2 \mathrm{mM})$ did not inhibit the $\mathrm{C} 5$ proteolytic activity present in CF lung fluids.

Table 2. Generation of C5a by CF BAL fluids: inhibition profile

\begin{tabular}{llll}
\hline \multicolumn{1}{c}{ Inhibitor $(\mathrm{mM})^{*}$} & CF BAL 1 & CF BAL 2 & CF BAL 3 \\
\hline Buffer solution & $3.03(0) \dagger$ & $3.74(0)$ & $4.14(0)$ \\
$\alpha-1-$ PI $(0.25 \mathrm{mg} / \mathrm{mL})$ & $1.30(57)$ & $2.11(44)$ & $1.99(52)$ \\
STI $(1 \mathrm{mg} / \mathrm{mL})$ & $1.03(66)$ & $1.92(49)$ & $1.61(61)$ \\
PMSF $(1)$ & $1.58(48)$ & $2.40(36)$ & $2.82(32)$ \\
Phenanthroline (1) & $2.26(25)$ & $2.28(39)$ & $2.65(36)$ \\
Phosphoramidon (0.06) & $2.83(7)$ & $1.95(48)$ & $2.36(43)$ \\
EDTA (50) & $1.77(42)$ & $2.78(26)$ & $2.98(28)$ \\
Leu (1) & $3.02(0)$ & $3.50(6)$ & $3.93(5)$ \\
\hline
\end{tabular}

* Concentration $(\mathrm{mM})$ added to BAL and then incubated with $200 \mathrm{ng}$ C5 substrate.

$\dagger \mathrm{C} 5 \mathrm{a}$ in ng produced $\left(\%\right.$ inhibition $\left.=\frac{\text { buffer }- \text { inhibitor }}{\text { buffer }} \times 100 \%\right)$.

tionship between pulmonary pathology in CF and infection with $P$. aeruginosa (33). In this study increasing numbers of Pseudomonads in CF sputum samples were closely associated with increased numbers of PMN leukocytes in the lavage fluids ( $p=$ 0.03 , controlling for total elastolytic activity and C5a concentrations). The CF subjects participating in this study had mild to
Table 3. Pseudomonas elastase generation of C5a

\begin{tabular}{lcc}
\hline \multicolumn{1}{c}{ Experiment } & $\begin{array}{c}\text { Repeated } \\
(n)\end{array}$ & $\begin{array}{c}\text { Mean C5a } \\
\text { by RIA* }\end{array}$ \\
\hline $\begin{array}{l}\mathrm{C} 5 \dagger+\text { phosphate-buffered saline, } \\
\mathrm{Ca}^{++}\end{array}$ & 6 & $2 \pm 0.5$ \\
$\mathrm{C} 5+$ Pseudomonas elastase $(10$ & 4 & $5.9 \pm 0.3$ \\
$\mathrm{ng})$ & 4 & $9.1 \pm 2.5$ \\
$\mathrm{C} 5+$ Pseudomonas elastase $(100$ & 8 & $10.1 \pm 1.8$ \\
$\quad \mathrm{ng})$ & & \\
$\begin{array}{l}\mathrm{C} 5+\text { Pseudomonas elastase }(300 \\
\text { ng) }\end{array}$ & & \\
\hline
\end{tabular}

* Expressed in $\mathrm{ng} / \mathrm{ml} \pm \mathrm{SEM}$.

$\uparrow 240$ ng C5 substrate.

moderate pulmonary disease as evidenced by the mean $x$-ray score (seven points deducted from possible 17) and clinical score (19 points deducted from a possible 75 ). Age of the CF patients participating in this study tended to vary directly with worsening radiology scores $(r=0.62, p=0.055)$. A poor prognosis is associated with an $\mathrm{x}$-ray score of more than 13 points deducted (34). Values for FEV 1 and FVC were those of patients with mild to moderate obstructive airways disease as well: mean $\mathrm{FEV}_{1} 2.9$ 


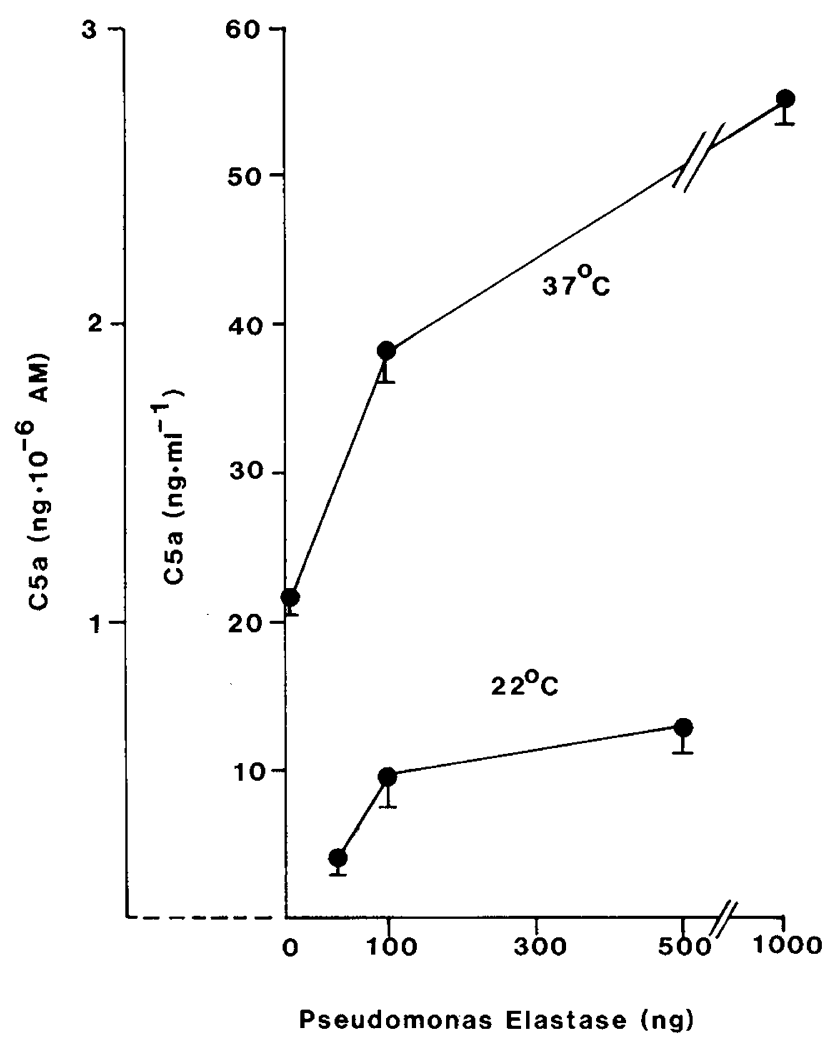

Fig. 8. Pseudomonas elastase generation of C5a from pulmonary macrophages. Pulmonary macrophages obtained from the airways of normal healthy volunteers cultured in the presence of elastase (abscissa) purified from $P$. acruginosa released C5a (ordinates) expressed as C5a released $\cdot \mathrm{ml}^{-1}$ or C5a released per $10^{-6}$ cells. C5a is released from PM in proportion to increasing elastase levels and the proteolysis yields greater amounts of $\mathrm{C} 5 \mathrm{a}$ at $37^{\circ} \mathrm{C}$ compared to $22^{\circ} \mathrm{C}$. At $37^{\circ} \mathrm{C} 100 \mathrm{ng}$ of enzyme resulted in a $71.4 \%$ increase, and 1000 ng caused a $149.8 \%$ increase in C5a released into culture supernatant compared to control cultures in the absence of purified bacterial enzyme.

liter \pm 0.4 (SEM) range 1.51-5.36 liter; mean FVC 3.7 liter \pm 0.5 , range 2.04-6.06 liter.

Increased elastolytic activity in $\mathrm{CF}$ respiratory secretions was associated with a loss of lung function. Each $10 \mathrm{ng} \cdot \mu \mathrm{g} \mathrm{TP} \mathrm{TP}^{-1}$ increase in BAL elastolytic activity was associated with a fall in $\mathrm{FEV}_{1}$ of 0.16 liter and a fall in FVC of 0.20 liter. The closest correlation between this proteolytic activity and the basic indices of lung function was obtained with the STI-inhibitable or serine proteinase fraction of elastolytic activity (for both $\mathrm{FEV}_{1}$ and FVC, $r>-0.93$ and $p<0.002$ ). Two of the CF patients demonstrated normal spirometry and lung volumes on routine testing. These were also the individuals with the lowest recorded concentrations of elastase $\left(0.72\right.$ and $\left.0.88 \mathrm{ng} \cdot \mu \mathrm{g} \mathrm{TP}{ }^{-1}\right)$ and lowest degree of complement activation $\left(<10\right.$ and $19 \mathrm{ng} \cdot \mathrm{ml}^{-1} \mathrm{C} 5 \mathrm{a} ; 0$ and $26 \% \mathrm{C} 3 \mathrm{c}$ ).

\section{DISCUSSION}

In these studies it was shown that: 1) chemotactic activity for neutrophils is significantly elevated in the lung fluids of patients with CF; 2) complement is activated in fresh lung fluids obtained from CF patients and activated complement components were absent in fluids from normal control subjects; 3) the anaphylatoxin $\mathrm{C} 5 \mathrm{a}$ is generated in CF fluids; 4) this complement polypeptide accounts, in part, for the elevated levels of leukoattractant activity present in these biologic fluids; and 5) both metalloenzymes and serine proteases contribute to the nonimmune proteolysis of free and cellbound C5.

Previous studies performed in this laboratory and a number of experiments reported herein support these conclusions. Work detailing decreased levels of $\mathrm{C} 3$ and increased relative amounts of $\mathrm{C} 3 \mathrm{c}$ in $\mathrm{CF}$ respiratory secretions (2) provided preliminary support for the contention that complement was activated in these airways. Both column chromatographic techniques and a sensitive RIA for C5a showed that C5a is a chemoattractant present in CF specimens and additional chemotactic- and C5agenerating activities are present in CF lung fluids. By supplementing CF lung lavage fluid specimens containing high levels of chemoattractant activity with more C5 substrate additional chemotactic activity was successfully generated. Adding CF BAL specimens to $\mathrm{C} 5$ resulted in cleavage of the $\alpha$-chain of this complement protein and the release of a $12,000 \mathrm{~mol} \mathrm{wt}$ fragment; a polypeptide with the same $\mathrm{mol} w \mathrm{wt}$ as $\mathrm{C} 5$ a generated by tryptic digestion of $\mathrm{C} 5$. Finally, Pseudomonas elastase and the proteolytic activity present in CF lung fluids released $\mathrm{C} 5 \mathrm{a}$ and chemotactic activity from normal PM monolayers.

These studies demonstrate a direct relationship between total elastolytic activity present in CF lung fluids and complement activation. Significant correlations observed between both the numbers of PMN leukocytes and the colony forming units of $P$ aeruginosa and the concentration of C5a present in CF specimens suggest that both Pseudomonas and neutrophils are possible sources of C5a-generating activity. In fact, it seems likely that the neutral metalloenzyme of Pseudomonas and the serine protease contained within the azurophil granules of neutrophils contribute to the cleavage of $\mathrm{C} 5$ yielding, in part, the active anaphylatoxin C5a. This conclusion is supported by the experiments showing that only by simultaneously employing both metalloproteinase inhibitors and serine proteinase inhibitors was it possible to: 1) block the chemotaxin-generating activity present within CF BAL fluids; and 2) prevent cleavage of the $\alpha$ - and $\beta$ chain of reduced $\mathrm{C} 5$, preventing generation of the chemotactic $12 \mathrm{KD}$ polypeptide. The thioproteinase inhibitor leupeptin used alone or in combination with other inhibitors did not have a similar effect. A thorough examination of agents known to inhibit the serine, thio-, and metalloproteinases did not identify a single agent capable of inhibiting the nonimmunologic production of $\mathrm{C} 5$ a from $\mathrm{C} 5$ by proteolytic activity contained within $\mathrm{CF}$ lung fluids (Table 2).

These results could have been predicted from previous observations that $\mathrm{CF}$ lung fluids contain increased numbers of PMN leukocytes, high levels of elastase, increased C3c (2) and the work, serving as a precedent, and performed in vitro by Orr et al. (4) and Ward and Hill (36). These investigators successfully demonstrated that $\mathrm{C} 5$ chemotactic fragments were produced by an enzyme in lysosomal granules of PMN leukocytes. The neutrophil-generated leukotactic activity was thought to be transient and rapidly replaced by chemotactic activity for tumor cells (4). Furthermore, the generation of these chemotactic activities from C5 was blocked by prior treatment of leukocyte preparations with the neutral protease inhibitor, trasylol. Presumably, leukocytic enzymes directly cleave C5 into the anaphylatoxin C5a, however, the chemotaxin generated in vitro by neutrophil enzymes $(4,36)$ was not definitely identified.

The upper and lower airways of patients with $\mathrm{CF}$ are obstructed by inflammatory secretions and mucopurulent plugging, and the lung disease is characterized by bronchiectasis with acute inflammatory cells obstructing the airways, ulcerating the mucosa, and infiltrating the submucosa. Bronchial-alveolar lavage fluid cell differential from CF specimens is inverted when compared to normal BAL specimens: greater than $60 \%$ of the cells obtained from CF airways are PMN leukocytes (2). Compatible with this leukocytosis in CF airways are two observations: 1) the levels of elastolytic activity present in CF respiratory secretions are strikingly elevated and 2) $70-80 \%$ of this proteolytic activity is a serine proteinase. The in vitro studies of Orr et al. (4) and Ward and Hill (36) would predict that such a milieu should favor the generation of $\mathrm{C} 5$ chemotactic activity.

A question has been raised as to whether elastase is anti- or 
proinflammatory. The work of Orr et al. (4) suggests that the C5 chemotactic activity generated with PMN leukocyte proteases is rapidly lost. The leukotactic activity produced by a 2 -min digestion of $\mathrm{C} 5$ by crude granule lysates was no longer present after a 60 -min incubation. However, it was demonstrated above that in these biologic fluids, CF lung lavage specimens, chemoattractant activity remained significantly elevated. Additionally, in vitro experiments employing the inhibitors of leukocyte serine proteinases (PMSF, $\alpha 1$-PI, STI) suggest that a nonserine protease contributes to the limited proteolysis of the $\alpha$ chain of $\mathrm{C} 5$ resulting in C5a generation (Fig. 7). P. aeruginosa is known to synthesize and release a metalloenzyme (24) which is capable of cleaving IgG opsonins $(37,38)$ in addition to providing the wellknown elastolytic properties of this bacterial protease. Schultz and Miller (39) convincingly demonstrated that a purified elastase from $P$. aeruginosa generated and then less rapidly inactivated a chemotactic factor from $\mathrm{C} 5$. Chemotactic activity generated from $\mathrm{C} 5$ by Pseudomonas elastase peaked at $60 \mathrm{~min}$ and was decreased when next measured at 120 min (39). Noting that C5 elastase-induced chemotactic activity was detectable only during incubations lasting less than $60 \mathrm{~min}$ these authors argued that this bacterial exoproduct had a potential antiinflammatory activity.

If, as suggested by Schultz and Miller (39), higher Pseudomonas enzyme concentrations inactivate $\mathrm{C} 5$ chemotactic activity and are antiinflammatory, one would predict very low levels of the chemotaxin C5a and, hence, low numbers of PMN leukocytes in these CF airways which are characterized by secretions with elevated levels of elastase activity. Such does not appear to be the case. Lung fluids obtained from CF patients contain high levels of chemotactic activity when compared to lung secretions from normal volunteers and the neutrophil is the predominant cell identified in the airway fluids. It seems likely that the in vitro systems of Orr et al. (4) and Schultz and Miller (39) are not analogous to the dynamic process in vivo. Rather than limited neutrophilic (4) or bacterial (39) proteases and complement components the $\mathrm{CF}$ airways are replenished by fresh neutrophils and complement proteins from the circulation. An additional explanation for the apparent discrepancy noted above is the existance of multiple nonproteolytic mechanisms for the generation of C5a chemotaxins. Gram-negative bacteria, such as $P$. aeruginosa, activate complement by both the classical and alternative pathways in the absence of antibody (40), and the classical pathway may be activated by bacterial-IgG and IgG immune complexes $(6,23)$.

Pulmonary macrophage proteolytic enzymes which are unique to this phagocytic cell have been incompletely studied, and therefore, specific inhibitors of macrophage proteases have not been identified. Accordingly, it is not possible to attribute in vivo nonimmune cleavage of $\mathrm{C} 5$ substrates to pulmonary macrophage-derived proteases. It is known that stimulated PM secrete a protease (41) capable of cleaving $\mathrm{C} 5$, but whether this is a unique protease synthesized by PM or an enzyme released by PMN leukocytes and then pinocytozed by PM as suggested by Campbell et al. (42) remains to be determined. However, the role of macrophage-derived proteins in the generation of C5a leukoattractant activity was examined (Fig. 8). These isolated cell culture experiments strongly suggest that PM possess $\mathrm{C5}$ polypeptides which are released when acted on by whole $\mathrm{CF}$ BAL fluids and the purified elastase of $P$. aeruginosa. The report of Sundamo and Gotze (43) and Robbins et al. (unpublished data) that cultured blood monocytes and pulmonary macrophages possess $\mathrm{C} 5$ bound to the surface of these cells serves as a precedent and suggest that the proteases in CF lung fluids cleave cell-bound $\mathrm{C} 5$ in a fashion similar to that demonstrated for $\mathrm{C} 5$ in solution (Table 3).

Complement activation by both neutrophil and bacterial proteases is of potential importance in a disease, such as $\mathrm{CF}$, in which upper and lower airways are filled with Pseudomonas and PMN leukocytes. $P$. aeruginosa respiratory infections occur in
58 to $85 \%$ of all CF patients (44). Colonization in the respiratory tracts of patients with CF by this persistent pathogen correlates with the progression of bronchial airway pathology (33). Pseudomonas infections and the patients' clinical states are also intimately related. Many clinicians have reported a direct correlation between the incidence of Pseudomonas colonization and age, clinical score, extent of pulmonary disease, and severity of changes on chest radiographs $(45,46)$. Indeed the number of colony forming units of $P$. aeruginosa present in the sputa of $\mathrm{CF}$ patients is closely related to the concentration of C5a present in BAL fluids. C5a and neutrophil elastolytic activity (STI-inhibitable) correlated in an inverse fashion with the tests of pulmonary function, $\mathrm{FEV}_{1}$ and FVC.

Recent studies from Switzerland have examined the possible role of granulocyte neutral proteases as mediators of airway destruction in patients with CF who were infected with Pseudomonas (47). They concluded that granulocyte neutral proteases and Pseudomonas may act synergistically in CF airways to contribute to the breakdown of elastin which occurs in progressive bronchiolar destruction. The present work demonstrates a persistent elevation of C5a leukoattractant in CF airways and provides a pathogenetic mechanism for the generation of this important mediator of inflammation. We suggest that both neutrophil serine proteases and Pseudomonas metalloenzymes act together, contributing to the direct nonimmune cleavage of $\mathrm{C5}$.

Acknowledgments. The authors wish to recognize the expert secretarial assistance of Deanna Ollendick, Mary Uhl, and Vanessa Krumbholz; and the additional technical assistance of Steven Strickler. Dr. Richard Ahrens, Department of Pediatrics, the University of Iowa, assisted with the enrollment of subjects and the process of informed consent and Dr. Gary W. Hunninghake offered many helpful suggestions during the preparation of this manuscript. Human C5a was provided by Dr. John Weiler, Division of Allergy and Clinical Immunology, University of Iowa.

\section{REFERENCES}

1. Kleinerman J 1977 Chronic bronchitis and cystic fibrosis: Two chronic obstructive lung diseases of adults. In: Boat TF, Petty TL (eds) "Gap" Conference Reports. Cystic Fibrosis Foundation, Atlanta, pp 5-6

2. Fick RB, Naegel GP, Squier SU, Wood RE, Gee JBL, Reynolds HY 1984 Proteins of the cystic fibrosis respiratory tract: fragmented IgG opsonic antibody causing defective opsonophagocytosis. J Clin Invest 74:236-248

3. Karlinsky JB, Snider GL 1978 Animal models of emphysema. Am Rev Respir Dis 117:1109-1133

4. Orr FW, Varani J, Kreutzer DL, Senior RM, Ward PA 1979 Digestion of the fifth component of complement by leukocyte enzymes. Am J Pathol 94:7583

5. Gotz M, Labec G 1978 Complement in cystic fibrosis. Eur J Pediatr 127:133139

6. Moss RB, Lewiston NJ 1980 Immune complexes and humoral responses to Pseudomonas aeruginosa in cystic fibrosis. Am Rev Respir Dis 121:23-29

7. Lorian V, Khauari P, Gray N 1967 Quantitative bacteriological analysis of sputum as a test of antibiotic efficacy. Appl Microbial 15:564-565

8. Fick RB, Naegel GP, Matthay RA, Reynolds HY 1981 Cystic fibrosis Pseudomonas opsonins. Inhibitory nature in an in vitro phagocytic assay. $\mathrm{J}$ Clin Invest 68:899-914

9. Niederman MS, Fritts LL, Merrill WW, Fick RB, Matthay RA, Reynolds HY, Gee JBL 1984 Demonstration of a free elastolytic metalloenzyme in human lung lavage fluid and its relationship to $\alpha$-1-antiprotease. Am Rev Respir Dis 129:943-947

10. Merrill WW, Naegel GP, Matthay RA, Reynolds HY 1980 Alveolar macrophage-derived chemotactic factor: kinetics of in vitro production and partial characterization. J Clin Invest 65:268-276

11. Bradford MM $1976 \mathrm{~A}$ rapid and sensitive method for the quantitation of microgram quantities of protein utilizing the principle of protein-dye binding. Anal Biochem 72:248-254

12. Ferric BC 1978 Recommended standardized procedures for pulmonary function testing. Am Rev Respir Dis 188(part 2):55-88

13. Bedell GN, Marshall R, DuBois AB, Comroe JH 1956 Plethysmographic determination of the volume of gas trapped in the lungs. J Clin Invest 35:664-670

14. Polgar G, Promadhat V 1971 Pulmonary Function Testing in Children: Techniques and Standards. WB Saunders Co., Philadelphia, pp 1-121

15. Nelson NM, Prod'hom LS, Cherry RB, Lipsitz PL, Smith CA 1967 Pulmonary function as the newborn infant. I. Methods: ventilation and gaseous metab- 
olism. Pediatrics 30.963-976

16. Taussig LM, Kattwinkel J, Friedenwald WT, di Sant Agnese PA 1973 A new prognostic score and clinical evaluation system for cystic fibrosis. J Pediat $82 \cdot 380-386$

17. Doershuk CF, Wood RE, Farrell PM 1978 Cystic Fibrosis Conference Reports Cystic Fibrosis Patient Evaluations and Scoring Systems. CF Foundation, Atlanta, Appendix

18. Hall DA. Czerkawski JW 1961 The reaction between elastase and elastic tissue 4. Soluble elastins. Biochem J 80:121-128

19. Dottavio-Martin D, Ravel JM 1978 Radiolabeling of proteins by reductive alkylation with $\left[{ }^{14} \mathrm{C}\right]$ formaldehyde and sodium cyanoborohydride. Anal Biochem 87:562-565

20. Mancini G, Carbonara AO, Heremans JF 1965 Immunochemical quantitation of antigens by single radial immunodiffusion. Immunochemistry 2:235-238

21. Axelsen NH. Kroll J, Weeks B 1973 A manual of quantitative immunoelectrophoresis. Methods and Applications. Scand $J$ Immunol 2(suppl 1):47-57

22. Tack BF. Prahl JW 1976 Third component of human complement purification from plasma and physiochemical characterization. Biochemistry 15:45134521

23. Hugli TE, Chenoweth DE 1980 Biologically active peptides of complement techniques and significance of $\mathrm{C} 3 \mathrm{a}$ and $\mathrm{C} 5 \mathrm{a}$ measurement. In: Nakamura RM (ed) Future Perspectives in Clinical Laboratory Immunoassays. Alan R. Liss, New York. pp 443-460

24. Morihara K, Tsuzuki H. Oka T, Inoue H, Ebata M 1965 Pseudomonas aeruginosa elastase. Isolation, crystallization, and preliminary characterization. J Biol Chem 240:3295-3304

25. Gallin JJ, Clark RA, Kimball HR 1973 Granulocyte chemotaxis: an improved in vitro assay employing ${ }^{51} \mathrm{Cr}$-labeled granulocytes. J Immunol 1 10:233-240

26. Hunninghake GW, Gadek JE, Fales HM, Crystal RG 1980 Human alveola macrophage-derived chemotactic factor for neutrophils. Stimuli and partial characterization. J Clin Invest 66:473-483

27. McFarlane AS 1964 Metabolism of plasma proteins. In: Munro NN, Allison JB (eds) Mammalian Protein Metabolism. Academic Press, New York, pp $331-349$

28. Laemmli UK 1970 Cleavage of structural proteins during assembly of the head of bacteriophages. Nature (Lond) 227:680-685

29. Henson PM, McCarthy K, Larsen GL, Webster RO, Giclas PC, Dreisen RB King TE. Shaw JO 1979 Complement fragments, alveolar macrophages and alveolitis. Am J Pathol 97:93-110

30. Hunninghake GW. Gallin JJ, Fauci AS 1978 Immunological reactivity of the lung. The in vivo and in vitro generation of a neutrophil chemotactic factor by alveolar macrophages. Am Rev Respir Dis 117:15-23

31. Hinman LM, Stevens CA. Matthay RA, Gee JBL 1980 Elastase and lysozyme in human alveolar macrophages. Am Rev Respir Dis 121:263-271

32. Gee JBL. Fick RB 1980 Bronchoalveolar Lavage. Thorax 35:1-8
33. Doggett RG, Harrison GM 1969 Significance of the bacterial flora associated with chronic pulmonary disease in cystic fibrosis. In: Lawson D (ed) Proceedings of the 5th International Cystic Fibrosis Conference, Cystic Fibrosis Research Trust, London, pp 175-188

34. Doershuk CF 1978 Clinical Scoring: State of the Art. In: Doershuk CF, Wood RE, Farrell PM (eds) Cystic Fibrosis Patient Evaluations and Scoring Systems, Cystic Fibrosis Conference Reports. Cystic Fibrosis Foundation, Atlanta, p 24-25.

35. Deleted in proof

36. Ward PA. Hill JH $1970 \mathrm{C} 5$ chemotactic fragments produced by an enzyme in lysosomal granules of neutrophils. J Immunol 104:535-543

37. Doring G, Obernesser HJ, Butzenhart K 1981 Extrazellulare toxine von Pseudomonas aeruginosa. II. Einwirkung zweier gereinigter Proteasen auf die menschlichen immunogbuline IgG, IgA und sekretorbches IgA. $3 \mathrm{~b} 1$. Bakt Hyg I. Abt Orig A 249:89-98

38. Fick RB, Baltimore RS, Squier SU, Reynolds HY 1985 The immunoglobulinG proteolytic activity of Pseudomonas aeruginosa in cystic fibrosis. $\mathrm{J}$ Infect Dis 151:589-598

39. Schultz DR, Miller KD 1974 Elastase of Pseudomonas aeruginosa: inactivation of complement components and complement-derived chemotactic and phagocytic factors. Infect Immun 10:128-135

40. Lambris J, Papamichail M, Ionnidis C, Dimitraco-Poulos 1982 Activation of the alternative pathway of human complement by the extracellular slime glycoprotein of Pseudomonas aeruginosa. J Infect Dis 145:78-83

41. Snyderman R, Shin HS, Dannenberg AM 1972 Macrophage proteinase and inflammation: The production of chemotactic activity from the fifth component of complement by macrophage proteinase. J Immunol 109:896-898

42. Campbell EJ, White RR, Senior RM, Rodriguez RJ, Kuhn C 1979 Receptormediated binding and internalization of leukocyte elastase by alveolar macrophages in vitro. J Clin Invest 64:824-833

43. Sundamo JS, Gotze O 1981 Human monocyte spreading induced by factor $\mathrm{Bb}$ of the alternative pathway of complement activation: a possible role for $\mathrm{C} 5$. J Exp Med 154:763

44. Fick RB 1981 Pseudomonas in cystic fibrosis: sylph or sycophant? Clin Chest Med 2:91-102

45. Hoiby N 1977 Pseudomonas aeruginosa infections in cystic fibrosis: diagnostic and prognostic significance of Pseudomonas aeruginosa precipitins determined by means of cross immunoelectrophoresis: a survey. Acta Path Microbiol Scand 262:1-96

46. Doggett RG, Harrison GM 1972 Immune status in patients with cystic fibrosis Infect Immun 6:628-635

47. Suter S, Schaad UB, Roux L, Nydegger UE, Waldvogel FA 1984 Granulocyte neutral proteases and pseudomonas elastase as possible causes of airway damage in patients with cystic fibrosis. J Infect Dis 149:523-531 